\title{
EXCESSIVE GROWTH OF FENNEL PONDWEED (Stuckenia pectinata) IN THE KIZILIRMAK RIVER, CAPPADOCIA, TURKEY
}

\author{
DEMIR, N. ${ }^{1 *}-$ BALCI, E. O. ${ }^{1}-$ FAKIOGLU, O. ${ }^{2}-$ KESKIN, E. ${ }^{3}-$ CoSKUN, T. ${ }^{1}$ \\ ${ }^{1}$ Ankara University, Faculty of Agriculture, Department of Fisheries and Aquaculture \\ Engineering, 06110 Ankara, Turkey \\ (phone: +90-312-596-1438) \\ ${ }^{2}$ Atatürk University, Faculty of Fisheries, Department of Fisheries Fundamental Sciences, \\ 25240 Erzurum, Turkey \\ (phone: +90-442-231-7052) \\ ${ }^{3}$ Ankara University, Faculty of Agriculture, Department of Fisheries and Aquaculture \\ Engineering, Evolutionary Genetics Laboratory (eGL), 06110 Ankara, Turkey \\ (phone: +90-312-596-1722) \\ ${ }^{*}$ Corresponding author \\ e-mail: ndemir@agri.ankara.edu.tr; phone:+90-312-596-1643 \\ (Received $12^{\text {th }}$ May 2021; accepted $30^{\text {th }}$ Aug 2021)
}

\begin{abstract}
An excessive growth of submerged vegetation has been observed in some regions of the Kizilırmak river. In this research, conducted below Yamula Dam, monthly changes in submerged macrophytes in the river course around Avanos (Nevsehir) were investigated. Submerged plant samples were taken from four stations and some water quality parameters were measured. The submerged plant which had increased excessively was identified as fennel pondweed, Stuckenia pectinata (L.) Börner. Molecular identification using a partial sequence of the ITS region has found that sampled S. pectinata specimens were not closer to sequences belonging to hybrid samples. Rather, nucleotide sequences of analysed fragment of ITS region have shown that the phytogeographic distribution of the haplotype, lies between eastern and western examples. The mean submerged plant biomass was estimated as $721 \pm 288 \mathrm{~g}$ dry weight $/ \mathrm{m}^{2}$ in the research period. The excessive increase of $S$. pectinata in the Kizllirmak can be attributed to the regulated flow in the river, and its salt tolerance and preference for hard waters. Since it was the single dominant species of submerged macrophyte in the study area, macrophytes indices could not be applied. Mechanical/physical control was recommended for the control of submerged plant biomass in the area.
\end{abstract}

Keywords: submerged plant, fennel pondweed, biomass, phylogenetics, impacts of dams

\section{Introduction}

Rivers are much more variable ecosystems than standing waters. From their source to their outflow, they are affected by the soils of the regions they flow through and climatic conditions. Streams originate from different sources, gradually widening and gouging out a bed until they flow into a lake or the sea. In this way, they show variations in their physical, chemical, and biological characteristics, which greatly affects people. Flowing waters are mostly affected by pollution, agricultural activity, and hydromorphological modifications such as dams: the lake forming behind a dam changes the river's flow regime.

Aquatic plants are the primary producers of this environment: they provide nutrition and shelter, and form a place for fish and other organisms to lay their eggs, and they have great importance in the sustainable use, management and restoration of the environment. Macrophytes affect the distribution, particle size and composition in the 
sediments of fresh and marine waters, and so their presence in freshwater and marine ecosystems is fundamental to improving water quality and to preventing turbidity and sediment mixing (Madson et al., 2001; Cirik et al., 2007).

Aquatic macrophytes directly affect water quality and its composition of organisms. In both flowing water and lakes, aquatic macrophytes are used as indicators in the monitoring of environmental effects and eutrophication, and macrophyte monitoring programs have been developed. Aquatic macrophytes are an important indicator in monitoring ecological quality especially in shallow lakes, but they can also be used as a measure of ecological quality in rivers (Melzer, 1999; Birk et al., 2006; Kuhar et al., 2011; Gecheva et al., 2013; Ciecierska and Kolada, 2014). The construction of dams and canals cause changes in the ecological characteristics of the water by affecting the flow. The Kizilirmak - 'Red River' - got its name from the characteristic red colour of the clay particles that it carries (Akbulut et al., 2009). Large dams constructed on the Kizilirmak have regulated its turbulent flow pattern, and over the long term, there has been a reduction in its flow. It has been found that with the reduction in the amount of alluvium, the Kizılırmak delta has ceased expanding (Bahadır, 2011). After the construction of the Yamula Dam, the increase in the black fly population in the middle Kızılırmak basin between the provinces of Kayseri and Nevşehir reached disastrous numbers. The flies were identified as black flies of Simuliidae species. Several researches were performed on the taxonomy of black flies in Turkey (Kazanc1 and Clergue-Gazeau, 1990; Kazanc1 and Ertunç, 2008; Başören and Kazanc1, 2016). This outbreak of flies had a negative effect on tourism and farming of this area of recreational importance (Y1lmaz et al., 2007). This species of fly lays its eggs on several substrates such as underwater plants, and we think that excessive plant growth had an effect on increasing the fly population. The larvae and pupa of the insects were observed on the aquatic plants. It is reported that commercial preparations containing Bacillus thuringiensis israelensis (Bti) were used against the fly larvae in the area (Yllmaz et al., 2010). The treatments against the flies in the river are still going on. In the River Nile, it was reported that the construction of the Aswan Dam caused important changes in the aquatic ecosystem and especially in aquatic plant communities and that with the regularization in the flow regime of the river, a suitable habitat was formed for the growth of many underwater macrophytes such as Ceratophyllum demersum and Stuckenia pectinata. It was also found that the increased plant growth was a factor in an increase of disease-carrying black flies (El-Shinnawy et al., 2000). Similarly, when large dams were built on the River Ebro in Spain, a reduction in suspended solid matter caused an increase in the species $S$. pectinata associated to the black fly Simulum erythrocephalum, and negative effects were reported on local people and tourists (Ibanez et al., 2008). Changes in river ecosystems can have many negative ecological consequences. The plants have caused an increase in the black fly population and have created recreational problems.

This research aims to identify the aquatic macrophytes of the Kizllırmak in the region of the district of Avanos in Cappadocia, to perform phylogenetic characterization of the excessively growing plant, and to investigate monthly changes in plant biomass. In addition, plant control methods have been discussed to suggest which one is the most suitable for the region. 


\section{Materials and methods}

\section{Study site and sampling}

The Kizilirmak is Turkey's longest river, and stretches for $1355 \mathrm{~km}$. It rises on the slopes of Kızıldağ in the north-east of Anatolia and runs through the provinces of Sivas, Kayseri, Nevşehir, Kırıkkale, Ankara, Çankırı, Çorum and Samsun, gathering water from many streams and rivers before meeting the Black Sea at Bafra. Kizilırmak is Turkey's second largest river basin, constituting approximately $10.9 \%$ of the total surface area of the country (Y1ldı and Özkıran, 1991). Its main tributaries are the Delice, Devrez and Gökırmak rivers. Fed with rain and snowmelt, the river used to have an irregular flow. It has a low rate of flow from July to February, and then in March it begins to swell rapidly, reaching its highest levels in April. Its mean flow rate is $184 \mathrm{~m}^{3} / \mathrm{s}$, while over a 35-year observation period its minimum mean flow was $18.4 \mathrm{~m}^{3} / \mathrm{s}$ and its maximum was $1673 \mathrm{~m}^{3} / \mathrm{s}$ (DSI, 2009). There are 16 dams on the river, and there are four dams upstream of the sites where samples were taken. This study was conducted on the section of the Kizilırmak below the Yamula Dam, where it passes through the district of Avanos in Cappadocia.

This study was conducted on a monthly basis between March and December 2010. Samples were taken from four stations between 38 $42^{\prime} 974^{\prime \prime}-38^{\circ} 43^{\prime} 050^{\prime \prime} \mathrm{N}$ and $34^{\circ} 51^{\prime} 526^{\prime \prime}-34^{\circ} 50^{\prime} 878^{\prime \prime} \mathrm{E}$ in the district of Avanos. Stations 3 and 4 were in the town of Avanos, and there was a distance of approximately $1470 \mathrm{~m}$ between stations 1 and 4 (Fig. 1). The width of river in the sampling stations changed between 55 and $125 \mathrm{~m}$. In the field work, the river was crossed from bank to bank by boat along a transect, and the frequency of occurrence of the water plants was recorded. The abundance of the plants was measured according to Kohler (1978) on a five-degree scale, from $1=$ very rare to $5=$ abundant, predominant. After that, the plants were taken from the bottom using a long-handled rake in three repetitions at equal distances from the sampling points (Westlake, 1986; Demir et al., 2020). Also, water samples were taken from immediately below the surface. The plants collected were placed in plastic bags and labelled.

Because of adverse weather conditions, plant samples were not taken from station 1 in July. In September, the river water was cut off to collect water in the newly constructed Bayramhacilı dam upstream of Avanos and the river bed was dry, so that plant samples could not be collected from stations 1, 2 and 4, and it was not possible to measure water depth or Secchi depth. However, it was possible to collect water samples from the flowing water.

\section{Analysis}

The aquatic plant was identified using a hand lens and stereomicroscope according to relevant literatures (Davis, 1965-1985). DNA extraction was performed using CTAB chloroform: isoamylalcohol method (Štorchová et al., 2000). The 18S rRNA, ITS1, 5.8S rRNA, ITS2, and 26S rRNA regions of the samples were amplified using the ITSF and ITS4 primer pair (Kaplan and Fehrer, 2004). PCR were carried out in a final volume of $50 \mu \mathrm{l}$ containing $8 \mu \mathrm{l}$ of $5 \mathrm{x}$ FIREPol Master Mix Ready to Load (12.5mMMgCl2) (Solis BioDyne, Estonia), $1 \mu \mathrm{l}$ of each primer (F, R), $2 \mu \mathrm{l}$ of template DNA and $28 \mu \mathrm{l}$ of $\mathrm{ddH}_{2} \mathrm{O}$. PCR amplifications were all set with a negative control sample. PCR amplifications were performed using a BioRad CFX96 thermal cycler using an initial denaturation step at $95^{\circ} \mathrm{C}$ for 7 minutes, followed by 35 cycles of denaturation at $94^{\circ} \mathrm{C}$ for 30 seconds, annealing at $48^{\circ} \mathrm{C}$ for 30 seconds, and extension at $72^{\circ} \mathrm{C}$ for 20 seconds 
and followed by a final extension at $72^{\circ} \mathrm{C}$ for 5 minutes (Keskin et al., 2016). PCR products of 945 base pairs were purified prior to sequencing. Bidirectional Sanger sequencing was performed using ABI SeqStudio Genetic Analyzer. Nucleotide sequences were aligned to reference sequences, and checked for possible reading errors, insertions and deletions. Analyses were performed based on a trimmed and quality checked 574 base pair fragment together with reference sequences obtained from NCBI GenBank. Nucleotide composition, nucleotide pair frequencies and codon usage were analysed for the nucleotide data and pairwise genetic distances were calculated using Jukes Cantor. The evolutionary relationship among species was analysed by constructing a Neigbor-Joining tree calculated using 1000 iteration bootstrap tests. All analyses were performed using MEGA X (Kumar et al., 2018). The biomass by unit area of aquatic plants was determined on the basis of dry weight. The plants were first sorted by species, and weighed. After the wet weight were measured, the samples of the plants were placed in weighed crucibles, dried in a desiccator at $105^{\circ} \mathrm{C}$ for 24 hours and cooled, after which dry weight was determined (Wetzel and Likens, 1991).

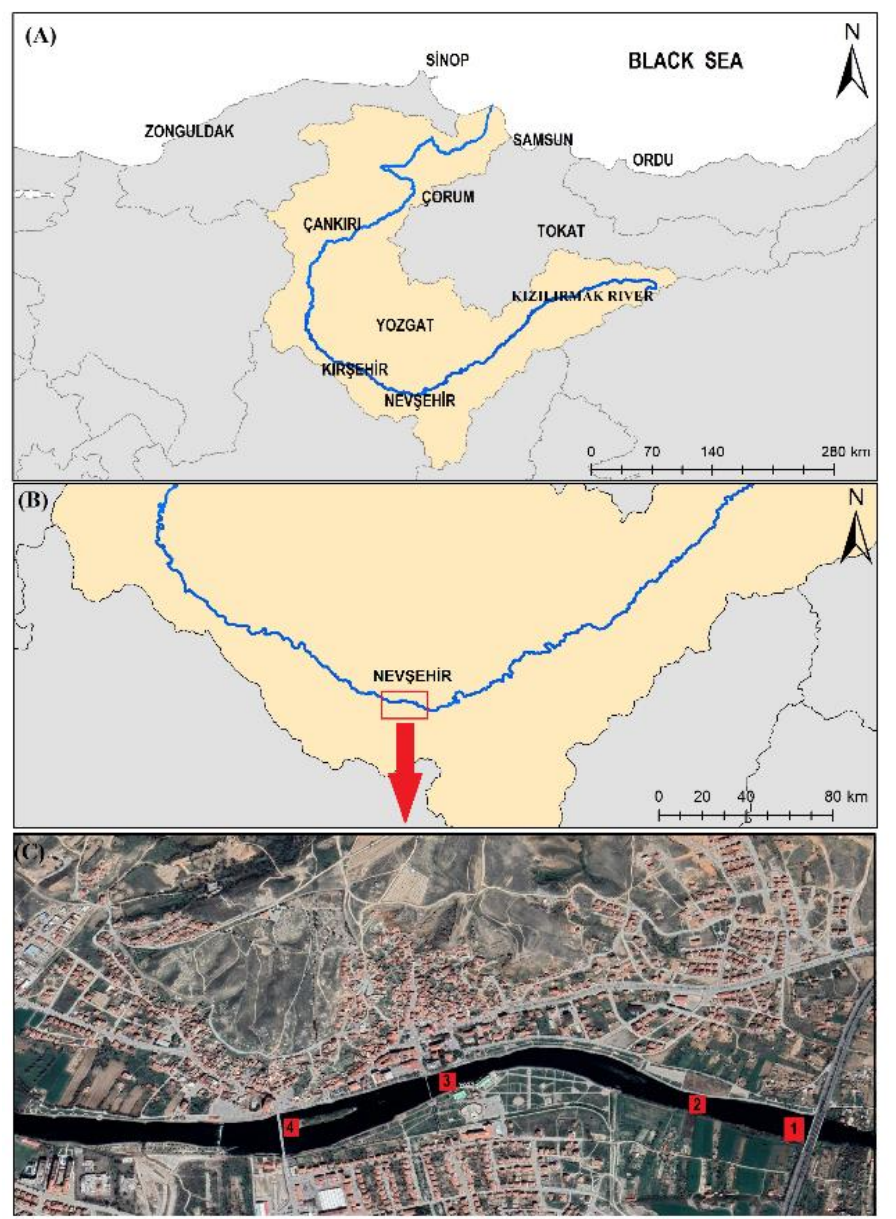

Figure 1. A; The location of Kizllırmak Basin, B, C; Study site and sampling stations

Measurements were made of water temperature, dissolved oxygen (with a YSI ProPlus Oxygenmeter), pH (with a Consort P901 Model pHmeter), electrical conductivity (with a Schott CG855 Model Conductivitymeter) and Secchi depth (with a 
20-cm diameter Secchi disk). Analyses of water samples for alkalinity, total hardness, nitrate, nitrite, ammonium, orthophosphate, total phosphorus were performed according to standard methods (APHA, 2005).

\section{Statistical analysis}

The variations of plant biomass between the sampling stations were evaluated by One-Way Analysis of Variance (ANOVA) and post-hoc Tukey test using SPSS 17 (Kesici and Kocabaş, 2007). For all parameters, logarithmic (Log X+1) data transformation was applied (except $\mathrm{pH}$ values). The Detrended Correspondence analysis (DCA) was used to select the appropriate model (linear or unimodal) for the ordination and it was determined by the Canoco v4.5 software (Ter Braak and Smilauer, 2002). According to the results, Principal Components Analysis (PCA) was applied by the covariance matrix at the XLSTAT 2014.5.03.

\section{Results and Discussion}

The species of aquatic plant showing an excessive increase in the sampling sites was determined as Stuckenia pectinata (L.) Börner (syn. Potamogeton pectinatus L.). Kaplan (2008), described the varieties and variation in Stuckenia species around the world, and separated them from the genus Potamogeton. Species grouped under the genus Stuckenia have long leaf sheaths, a characteristic leaf and a pendiculous anatomy, with a high ploidy level (hexaploidy) distinguishing them from the generally diploid or tetraploid Potamogeton species. However, hybridization with other Potamogeton species makes identification by morphological characteristics difficult.

Genetic characterization of the species Stuckenia pectinata was performed using the ITS region, and phylogenetic analyses were made comparing it with Stuckenia pectinata, Stuckenia filiformis as outgroup and Stuckenia pectinata $x$ Stuckenia filiformis hybrid samples from various countries (Table 1, Fig. 2). Molecular methods have been used to distinguish Stuckenia and Potamogeton species. The nuclear ITS region has become the most used marker because it provides the possibility of copying both maternally and paternally derived DNA sequences. Results obtained show variation between species to be up to $1-1.3 \%$ level within species and hybrids and up to $4 \%$ among S. pectinata and filiformis specimens. In nucleotide composition analysis results, the mean G-C ratio was calculated to be $50.7 \%$ and the ratio of transitional pairs to transversional pairs was found to be $\mathrm{R}=0.49$. The mean genetic difference between the samples used in the analysis was calculated to be 0.02. Examining the tree constructed by the Neighbor-Joining method, it was seen that the specimen obtained from Turkey was identical with the reference sequence gathered from Czech Republic in terms of nucleotide composition. After examining the DNA sequences of the samples of $S$. pectinata taken in the section of the Kizilirmak and comparing them with DNA sequences in the literature and in international data banks, it was concluded that it was not a hybrid as it is clustered with $S$. pectinata specimen from Czech Republic, very close to other $S$. pectinata specimen from China and clearly separated from $S$. pectinata x S. filiformis hybrid specimen and S. filiformis specimens. These results strengthen the idea that the ITS region is a suitable gene for genetic characterization, including the phylogeographic analysis of the species $S$. pectinata. It is intended in future studies to analyse different populations of the species, thereby revealing the genetic structure of the populations of Turkey. 
Table 1. Pairwise genetic distance matrix of S. pectinata haplotype sequenced in this study together with reference sequences from different countries gathered from NCBI GenBank

\begin{tabular}{|c|c|c|c|c|c|c|c|}
\hline & & 1 & 2 & 3 & 4 & 5 & 6 \\
\hline 1 & Stuckenia pectinata (This study-Turkey) & & 0.000 & 0.004 & 0.004 & 0.008 & 0.008 \\
\hline 2 & $\begin{array}{c}\text { MH171027 Stuckenia pectinata (Czech } \\
\text { Republic) }\end{array}$ & 0.000 & & 0.004 & 0.004 & 0.008 & 0.008 \\
\hline 3 & DQ840277 Stuckenia pectinata (China) & 0.013 & 0.013 & & 0.002 & 0.007 & 0.007 \\
\hline 4 & $\begin{array}{l}\text { FJ956925 Stuckenia pectinata x Stuckenia } \\
\text { filiformis (China) }\end{array}$ & 0.010 & 0.010 & 0.003 & & 0.007 & 0.007 \\
\hline 5 & KT175311 Stuckenia filiformis (China) & 0.041 & 0.041 & 0.033 & 0.030 & & 0.000 \\
\hline 6 & $\begin{array}{l}\text { MH171032 Stuckenia filiformis (Czech } \\
\text { Republic) }\end{array}$ & 0.041 & 0.041 & 0.033 & 0.030 & 0.000 & \\
\hline
\end{tabular}

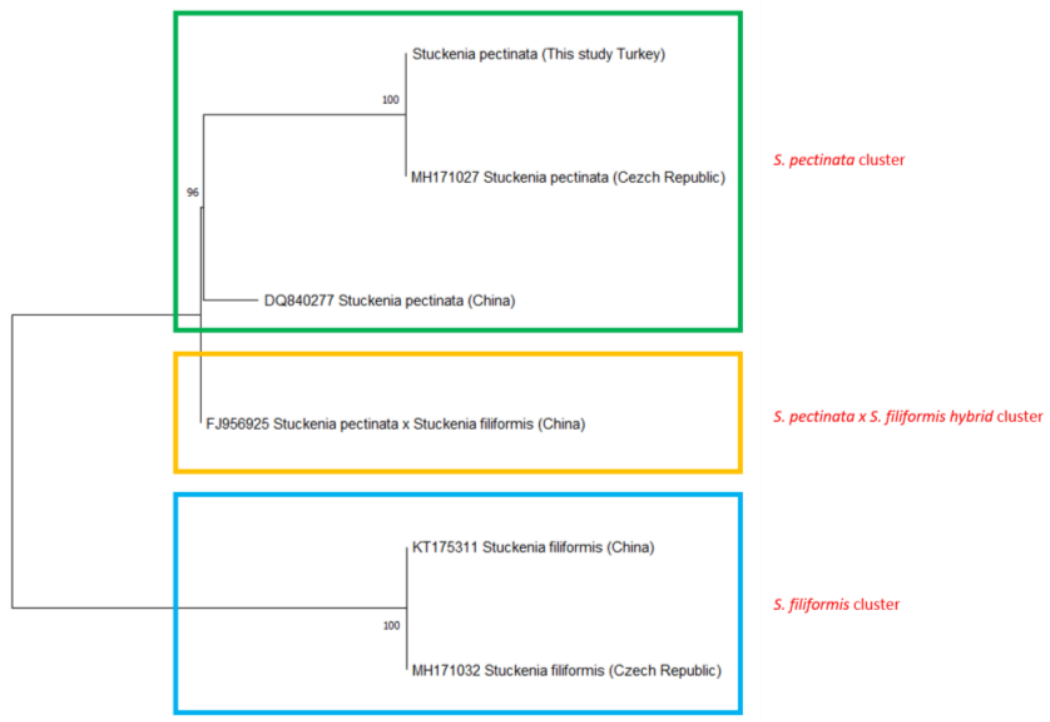

Figure 2. Phylogenetic relationship (Neighbor-joining tree with Jukes Cantor estimation via 1000 bootstrap tests) among $S$. pectinata specimens sequenced in this study and specimens from other countries gathered from NCBI GenBank

S. pectinata was not reported around Avanos before dam construction, but grew excessively when flow was regulated by dams. The Kizılirmak is faced with a great threat of pollution. In a research covering all Kizilırmak basin, 73\% of stations are below good ecological status according to diatom index (EPI-D) and eutrophication/organic pollution are reported (Çetin et al., 2021). The name of the river - Kizılirmak means 'red river' - comes from the characteristic reddish colour of the clay particles which it carries (Akbulut et al., 2009). Dams built on the river have affected the flow regime, and it has been found that the growth of the Kizilirmak delta has ceased because of a reduction in the amount of alluvium (Bahadir, 2011). $S$. pectinata is a cosmopolitan species, lives in almost all waters and adapts to different environments. It was reported from the wetlands of the Kizılirmak basin, delta and 
Sultan Sazligi and widely distributed in Turkey in lakes and wetlands, from freshwaters to brackish lagoons and ponds (Seçmen and Leblebici, 1997; Demirezen and Aksoy, 2004). S. pectinata is a monocotyledonous angiosperm of the Potamogetonaceae family. It is a perennial macrophyte species, one of the most widespread aquatic plants, growing in fresh or brackish water, in stagnant water, in wet areas and in flowing water. It can grow excessively in irrigation canals and recreational areas. Its seeds are resistant to drying and high salinity, and are spread by water birds. It can also tolerate changes in water level. Among Potamogeton species, only S. pectinata tolerates high salinity, $\mathrm{pH}$ and alkalinity; it can be found in eutrophic waters and can even live in very polluted areas (Kantrud, 1990).

The mean depth of the sampling area was found as $2.25 \pm 0.44 \mathrm{~m}$, and Secchi depth was $0.90 \pm 0.20 \mathrm{~m}$. Water depth and Secchi depth showed monthly variation over the study period and monthly variation in Secchi depth was significant $(F=16.47, p=0.00)$ (Table 2). The lowest Secchi depth were found to be lower than the values from the Yamula dam lake. In the Yamula dam, situated on the Kizilırmak in the upstream, the Secchi depth varied from 0.85 to $4.70 \mathrm{~m}$ (DSI, 2009). The dam lake causes an increase in the Secchi depth. One of the most important abiotic factors limiting macrophyte development is light penetration in the water. In clean water with high light intensity, the plant size, internode length and leaf length of $S$. pectinata are reduced, while in turbid waters with low light intensity, plant size, internode length and leaf length are increased (Santamaria, 2002). It has been reported that S. pectinata is found in running water habitats of less than $2.5 \mathrm{~m}$ depth (Kantrud, 1990). According to this, the depth of the sampling stations was suitable for plant growth. The height of the plants varied between 1.43 and $3.1 \mathrm{~m}$ in research period. It is thought that the excessive growth of S. pectinata in the Kizılırmak means that it has adapted to low light intensity and high salinity so that it has covered the whole river bed and grown up to the surface.

Water temperature at the sampling stations increased from March onwards, and the highest temperature, $14.9^{\circ} \mathrm{C}$, was measured in July (Table 2). Dissolved oxygen concentrations at the sampling stations varied from 11.1 to $15.2 \mathrm{mg} / \mathrm{l}, \mathrm{pH}$ from 6.9 to 8.3 , and conductivity from 1000 to $1291 \mu \mathrm{S} / \mathrm{cm}$. The variation in parameters between sampling stations was found not to be statistically significant, but the monthly variations were significant ( $\mathrm{F}$ and $\mathrm{P}$ values of these parameters are; Water temperature $\mathrm{F}=45.214$, $\mathrm{p}=0.00$, Dissolved oxygen $\mathrm{F}=47.76, \mathrm{p}=0.00, \mathrm{pH} \mathrm{F}=63,70, \mathrm{p}=0.00$, Conductivity $\mathrm{F}=2.20, \mathrm{p}=0.049$ ).

Mean alkalinity in the Kızılırmak was determined as $81.58 \pm 18.89 \mathrm{mg} \mathrm{CaCO}_{3} / \mathrm{l}$, and the mean total hardness value was $39.10 \pm 6.91^{\circ} \mathrm{FS}$. the river flows through generally gypsum soils and it has high conductivity. The tolerance of macrophytes for salinity varies. Many freshwater plants are very sensitive to increasing salinity, but $S$. pectinata can grow in saline waters. It is reported that $S$. pectinata is found in waters with a $\mathrm{pH}$ of between 6.3 and 10.7, and an alkalinity of 0.018 to $34.7 \mathrm{~g} / \mathrm{L} \mathrm{CaCO}_{3}$ (Kantrud, 1990). It was found that $S$. pectinata was widespread, and occurred at high alkalinity and $\mathrm{pH}$ values, and used bicarbonate effectively as a source of dissolved inorganic carbon (Vestergaard and Sand-Jensen, 2000). Kizılırmak are in the category of very hard waters in terms of total hardness. The chemical characteristics of the water have an important effect on the macrophyte community. The relationships between calcium concentration, hardness, dissolved inorganic carbon and $\mathrm{pH}$ affect macrophyte composition (Fox, 1992). It is thought that one of the reasons for the excessive increase in S. pectinata in the Kizilırmak are its salt tolerance and its preference for hard waters. 
Table 2. Monthly changes of physical and chemical water quality parameters in in Kuzllirmak river during research (mean \pm standard deviation)

\begin{tabular}{|c|c|c|c|c|c|c|c|c|c|c|c|}
\hline $\begin{array}{c}\text { WQ } \\
\text { Parameters }\end{array}$ & $\begin{array}{c}\text { March } \\
n=4\end{array}$ & $\begin{array}{c}\text { April } \\
n=4\end{array}$ & $\begin{array}{l}\text { May } \\
n=4\end{array}$ & $\begin{array}{c}\text { June } \\
n=4\end{array}$ & $\begin{array}{l}\text { July } \\
\mathrm{n}=4\end{array}$ & $\begin{array}{c}\text { August } \\
n=4\end{array}$ & $\begin{array}{c}\text { Septem. } \\
n=4\end{array}$ & $\begin{array}{c}\text { October } \\
n=4\end{array}$ & $\begin{array}{c}\text { November } \\
n=4\end{array}$ & $\begin{array}{c}\begin{array}{c}\text { December } \\
n=4\end{array} \\
\end{array}$ & $\begin{array}{c}\text { Mean } \pm \text { SD } \\
\mathbf{n}=44^{*}\end{array}$ \\
\hline $\begin{array}{l}\text { Depth } \\
(\mathrm{cm})\end{array}$ & $125 \pm 31$ & $246 \pm 11$ & $227 \pm 33$ & $250 \pm 14$ & $205 \pm 17$ & $220 \pm 8$ & - & $268 \pm 30$ & $248 \pm 13$ & $235 \pm 24$ & $226 \pm 44$ \\
\hline $\begin{array}{l}\text { Secchi D } \\
(\mathrm{cm})\end{array}$ & $98 \pm 17$ & $69 \pm 8$ & $91 \pm 6$ & $88 \pm 9$ & $108 \pm 12$ & $110 \pm 8$ & - & $50 \pm 0$ & $96 \pm 11$ & $103 \pm 9$ & $90 \pm 20$ \\
\hline $\begin{array}{l}\text { Wat Temp } \\
\left({ }^{\circ} \mathrm{C}\right)\end{array}$ & $4.1 \pm 0.1$ & $10.9 \pm 0.4$ & $10.7 \pm 0.4$ & $11.8 \pm 0.1$ & $14.9 \pm 0.1$ & $14.3 \pm 3.0$ & $11.7 \pm 0.4$ & $8.9 \pm 0.5$ & $7.9 \pm 0.1$ & $6.9 \pm 0.1$ & $10.2 \pm 3.3$ \\
\hline $\mathrm{pH}$ & $7.15 \pm 0.19$ & $8.09 \pm 0.02$ & $7.93 \pm 0.10$ & $7.96 \pm 0.10$ & $8.32 \pm 0.02$ & $8.25 \pm 0.02$ & $8.03 \pm 0.05$ & $8.26 \pm 0.04$ & $8.21 \pm 0.02$ & $7.96 \pm 0.11$ & $8.01 \pm 0.33$ \\
\hline $\begin{array}{c}\mathrm{EC} \\
(\mu \mathrm{S} / \mathrm{cm})\end{array}$ & $1264 \pm 26$ & $1132 \pm 59$ & $1178 \pm 70$ & $1113 \pm 84$ & $1210 \pm 42$ & $1137 \pm 60$ & $1181 \pm 47$ & $1167 \pm 47$ & $1190 \pm 62$ & $1209 \pm 71$ & $1178 \pm 67$ \\
\hline $\begin{array}{l}\text { D. Oxygen } \\
\left(\mathrm{mgO}_{2} / \mathrm{l}\right)\end{array}$ & $12.7 \pm 0.3$ & $11.9 \pm 0.2$ & $12.2 \pm 0.2$ & $11.8 \pm 0.4$ & $13.1 \pm 0.1$ & $11.5 \pm 0.4$ & $11.6 \pm 0.3$ & $14.8 \pm 0.4$ & $12.9 \pm 0.3$ & $11.9 \pm 0.2$ & $12.4 \pm 0.9$ \\
\hline $\begin{array}{l}\mathrm{NH}_{4}-\mathrm{N} \\
(\mathrm{mg} / \mathrm{l})\end{array}$ & $1.16 \pm 0.08$ & $0.99 \pm 0.07$ & $0.93 \pm 0.06$ & $1.0 \pm 0.06$ & $0.89 \pm 0.09$ & $0.90 \pm 0.08$ & $0.90 \pm 0.05$ & $1.15 \pm 0.12$ & $0.93 \pm 0.04$ & $0.79 \pm 0.11$ & $0.96 \pm 0.13$ \\
\hline $\begin{array}{l}\mathrm{NO}_{2}-\mathrm{N} \\
(\mathrm{mg} / \mathrm{l})\end{array}$ & $0.08 \pm 0.01$ & $0.03 \pm 0.01$ & $0.02 \pm 0.01$ & $0.01 \pm 0.0$ & $0.01 \pm 0.0$ & $0.01 \pm 0.0$ & $0.02 \pm 0.0$ & $0.13 \pm 0.01$ & $0.04 \pm 0.01$ & $0.04 \pm 0.0$ & $0.04 \pm 0.02$ \\
\hline $\begin{array}{l}\mathrm{NO}_{3}-\mathrm{N} \\
(\mathrm{mg} / \mathrm{l})\end{array}$ & $2.94 \pm 0.59$ & $1.75 \pm 0.23$ & $1.83 \pm 0.28$ & $1.67 \pm 0.43$ & $1.64 \pm 0.32$ & $1.90 \pm 0.21$ & $2.05 \pm 0.43$ & $3.14 \pm 0.73$ & $1.88 \pm 0.05$ & $1.23 \pm 0.08$ & $2.0 \pm 0.66$ \\
\hline $\begin{array}{l}\mathrm{PO}_{4}-\mathrm{P} \\
(\mathrm{mg} / \mathrm{l})\end{array}$ & $0.02 \pm 0.003$ & $0.01 \pm 0.0$ & $0.011 \pm 0.0$ & $0.01 \pm 0.0$ & $0.01 \pm 0.0$ & $0.02 \pm 0.0$ & $0.02 \pm 0.01$ & $0.03 \pm 0.01$ & $0.02 \pm 0.01$ & $0.01 \pm 0.0$ & $0.02 \pm 0.01$ \\
\hline $\begin{array}{c}\mathrm{TP} \\
(\mathrm{mg} / \mathrm{l})\end{array}$ & $0.035 \pm 0.01$ & $0.024 \pm 0.0$ & $0.028 \pm 0.0$ & $0.023 \pm 0.0$ & $0.033 \pm 0.0$ & $0.042 \pm 0.0$ & $0.028 \pm 0.0$ & $0.051 \pm 0.0$ & $0.04 \pm 0.0$ & $0.032 \pm 0.0$ & $0.034 \pm 0.01$ \\
\hline $\begin{array}{l}\text { Hardness } \\
\left({ }^{\circ} \mathrm{FS}\right)\end{array}$ & $39.8 \pm 2.2$ & $38.5 \pm 1.9$ & $36.8 \pm 0.5$ & $37.0 \pm 1.8$ & $38.9 \pm 2.6$ & $36.0 \pm 6.0$ & $35.3 \pm 3.9$ & $28.7 \pm 2.3$ & $50.9 \pm 4.7$ & $49.1 \pm 3.7$ & $39.1 \pm 6.9$ \\
\hline $\begin{array}{c}\text { Alkalinity } \\
\left(\mathrm{mgCaCO}_{3} / \mathrm{l}\right)\end{array}$ & $80.0 \pm 16.3$ & $85.0 \pm 10.0$ & $72.5 \pm 18.9$ & $77.5 \pm 5.0$ & $85.0 \pm 19.2$ & $75.0 \pm 10.0$ & $87.5 \pm 9.6$ & $117.5 \pm 17.1$ & $70.0 \pm 20.0$ & $65.0 \pm 10.0$ & $81.5 \pm 18.9$ \\
\hline $\begin{array}{l}\text { Flow** } \\
\left(\mathrm{m}^{3} / \mathrm{s}\right)\end{array}$ & 62.6 & 174.7 & 95.3 & 58.9 & 56.2 & 75.5 & 77.8 & 75.3 & 97.6 & 94.1 & 83.7 \\
\hline
\end{tabular}

"the number of repetitions, "* Monthly values of outflow after Yamula Dam was taken from General Directorate of State Hydraulic Works 
PCA of plant biomass and environmental parameters showed that water temperature, $\mathrm{pH}$, total phosphorus and alkalinity affected plant biomass positively. The first two axes of PCA accounted for $80 \%$ of the total variance (Fig. 3). But plant biomass was negatively affected with flow rate. It was found that in the River Wye, there was a negative correlation between the speed of flow and the macrophyte cover and biomass. Similarly, in Switzerland, it was found that when the flow of a river was below $0.3 \mathrm{~m} / \mathrm{s}$, the macrophyte cover increased, but that it decreased at higher rates of flow (Wade, 1994). Increases in flow rates cause reductions in macrophyte biomass. When flow rate increased, biomass and shoot density were observed to decrease (Chambers et al., 1991). Monthly mean values of outflows from the Yamula Dam in research period are given in Table 2. The mean outflow rate from the Yamula dam during the study period was $83.7 \mathrm{~m}^{3} / \mathrm{s}$, and the highest flow was in April at $174.7 \mathrm{~m}^{3} / \mathrm{s}$ (DSI, 2009). According to measurements made in April on the $4^{\text {th }}$ sampling station, the flow rate was $0.5 \mathrm{~m} / \mathrm{s}$. It has been reported that $S$. pectinata spreads in waters with a flow rate of less than $1 \mathrm{~m} / \mathrm{s}$ (Kantrud, 1990). Water flow is one of the most important abiotic factors affecting the location and composition of plant communities in rivers.

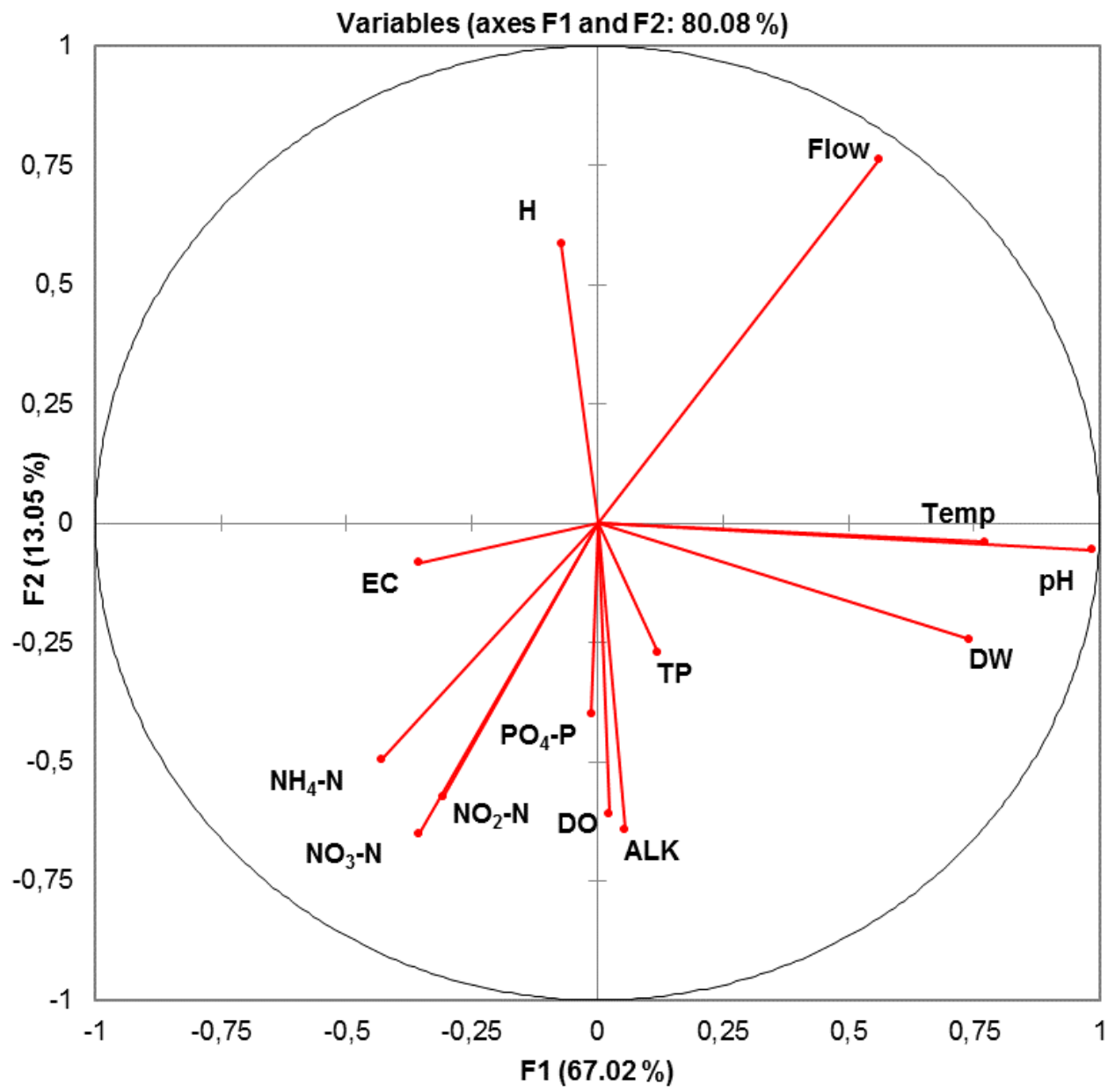

Figure 3. PCA of macrophyte biomass and environmental parameters in Klzllirmak. DW: dry weight of plants, Temp: water temperature, EC: conductivity, DO: dissolved oxygen, ALK: alkalinity, $\mathrm{H}$ : hardness, TP: total phosphorus, $\mathrm{PO}_{4}-\mathrm{P}$ : orthophosphate, $\mathrm{NO}_{2}-\mathrm{N}$ : nitrite-nitrogen, $\mathrm{NO}_{3}-\mathrm{N}$ : nitrate-nitrogen, $\mathrm{NH}_{4}-\mathrm{N}$ ammonium-nitrogen 
During the period of the study, the above-ground biomass of S. pectinata increased from March to August (Fig. 4). In September, the river bed was emptied to fill the Bayramhacilı dam, and so the amount of plant biomass declined. However, in October, November and December, it was found to be high again. Over the study period, the mean plant biomass varied from 226 to $1086 \mathrm{~g}$ dry weight $/ \mathrm{m}^{2}$ and the mean plant biomass was found to be $720.9 \pm 288.0 \mathrm{~g} / \mathrm{m}^{2}$. S. pectinata biomass that it varies from $>5$ to $1988 \mathrm{~g}$ dry weight $/ \mathrm{m}^{2}$, and that plant growth is limited by turbidity, other macrophytes and competing species, water flow, wind, wave movement, changes in water depth, pollution and eutrophication, grazing by fish and water birds, excessive salinity, sediment, river bottom construction and toxic materials (Kantrud, 1990). The variation in $S$. pectinata biomass by sampling stations was found to be statistically insignificant, but the monthly variation was found to be significant $(F=21.52, p=0.00)$ (Fig. 4). According to the Tukey test, the highest mean biomass was recorded in November (significanly higher than March, April, May, June, July and September, $\mathrm{p}<0.05)$. The variations between the plant biomass in June, July, August, September, October and December were not statistically significant.

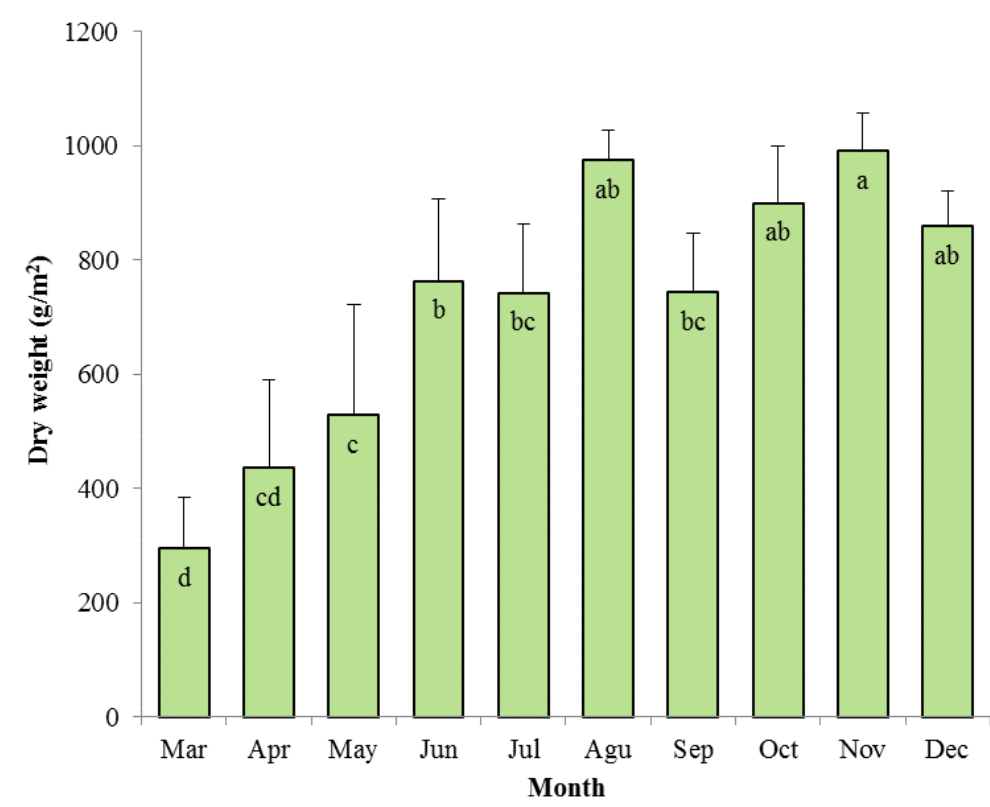

Figure 4. Monthly mean values of plant biomass ( $g$ dry weight $\left./ \mathrm{m}^{2}\right)$ and standard deviations (vertical lines on bars) $(n=4)$ in Klzllirmak. Variations of the mean biomass with different letters $(a, b, c)$ at each bar are statistically significant according to the post-hoc, Tukey test $(p<0.05)$

The distribution of the aquatic plant $S$. pectinata in the Kizllirmak was found to be predominant ( $1=$ very rare, $2=$ rare, $3=$ widespread, $4=$ common, $5=$ predominant $)$. Because only one species was predominant in the Kizılırmak, macrophyte indices could not be used in determining ecological quality. The indices used for this purpose are applied when there are at least three, or two, species (Schneider and Melzer, 2003; Kuhar et al., 2011). Nevertheless, according to Melzer (1999), S. pectinata is in indicator group 4 which indicates heavy organic pollution in lakes. Kuhar et al. (2011) developed River Macrophyte Index to determine the ecological condition of rivers, and 
reported S. pectinata to be in group B, with ecologically medium level pollution load. The ecological status of Kizilirmak river in the same locations (R16 and R17) were also found as medium according to diatom indexes (Çetin et al., 2021). Kızılırmak and its tributaries were subjected to several impacts. S. pectinata is tolerant of eutrophication and salinity. It is thought that its excessive growth in the Kizılırmak along with other factors is an indicator of organic pollution.

Among the aquatic plant control methods, biological control and chemical control methods are not suggested for Kizılirmak river. Biological control methods possess the danger of spreading non-targeting organisms. The use of grass carp was not suggested because of the spreading non-native fish to river ecosystem. It was reported that herbicides can control $S$. pectinata in static or slow flowing rivers. But, the turions are unaffected and regrow after the herbicide degraded (CEH, 2004). Chemical methods such as the herbicide application is not suitable for Kizilirmak river because of high flow rate and the use of river water as drinking water in the river course. Pondweeds can be cut but regrowth is often rapid after early season cuts (CEH, 2004). The possible aquatic plant control method for the river may be physical/mechanical control by the means of harvesters or water level/flow rate control by the means of dams.

\section{Conclusions}

In conclusion, $S$. pectinata in the K1z1lirmak constitutes a problem for the recreational use of the river. The plant was not previously found in the section of the river passing through the district of Avanos, but now forms a dense plant cover. It is thought that the main reason for the excessive growth of the S. pectinata is regulated flow by dams. Physical/mechanical methods are recommended for the control of aquatic plants in the Kizllirmak. However, the most suitable time and cutting periods, the design of machinery resistant for the high flow, and the uses for the cut plant material need further investigation. Future studies may focus on the location-specific applicability of the control methods based on field test.

Acknowledgements. This study was funded by The Scientific and Technological Research Council of Turkey (TUBITAK), Project No: 110Y210. We are grateful to Vet. Ahmet Demircioglu and Avanos Municipality for their help in the field studies.

Author contribution. Nilsun Demir and Eniz Ozge Balc1 conceptualized and planned the study. Nilsun Demir, Eniz Ozge Balcı and Ozden Fakıoglu conducted the field studies and laboratory studies. Ozden Fakıglu conducted nutrient analysis. Emre Keskin conducted phylogenetic analysis and Tolga Coşkun conducted statistical analysis and laboratory analysis. Nilsun Demir interpreted the results and wrote the text with contributions of all authors.

\section{REFERENCES}

[1] Akbulut, E. N., Bayarı, S., Akbulut, A., Sahin, Y. (2009): Rivers of Turkey. - In: Tockner, K., Robinson, C. T., Uehlinger, U. (eds.) Rivers of Europa. Academic, New York.

[2] APHA (2005): Standard methods for the examination of water and wastewater (Vol. 21). - American Public Health Association, Washington DC.

[3] Bahadır, M. (2011): A statistical analysis of the flow changes in Kizılırmak river. Turkish Studies 6(3): 1339-1356. 
[4] Başören, Ö., Kazanc1, N. (2016): A checklist of Simuliidae (Insecta, Diptera) species of Turkey. - Review of Hydrobiology 9(2): 153-164.

[5] Birk, S., Korte, T., Hering, D. (2006): Intercalibration of assessment methods for macrophytes in lowland streams: direct comparison and analysis of common metrics. Hydrobiologia 566: 417-430.

[6] CEH (2004): Information sheet 9: Fennel pondweed. - Natural Environment Research Council Centre for Ecology \& Hydrology, Centre for Aquatic plant management, Wallingford, UK.

[7] Çetin, T., Solak, C. N., Y1lmaz, E. (2021): Testing the performance of European diatom indices for evaluating the ecological status in the Kiz1lırmak basin, Turkey: flowing waters. - Environmental Science and Pollution Research. https://doi.org/10.1007/s11356021-13282-1.

[8] Chambers, P. A., Prepas, E. E., Hamilton, H. R., Bothwell, M. L. (1991): Current velocity and its effects on aquatic macrophytes in flowing waters. - Ecological Applications 1: 249-257.

[9] Ciecierska, H., Kolada, A. (2014): ESMI: a macrophyte index for assessing the ecological status of lakes. - Environmental Monitoring and Assessment 186(9): 5501-5517.

[10] Cirik, S., Cirik, Ş., Conk-Dalay, M. (2007): Aquatic Plants 2. - Ege Univ. Fisheries Fac. Publishing, Izmir. (in Turkish).

[11] Davis, P. H. (1965-1985): Flora of Turkey and the East Aegean Islands, Vol: 1-9. Edinburgh University Press, Edinburgh.

[12] Demir, A. N., Levi, E., Coşkun, T., Özen, A., Yaprak, A. E. (2020): Biological Variables: Aquatic Plants. - In: Tavşanoğlu, Ü. N., Başaran Kankılıç, G., Erdoğan, Ş. (eds.) Field and Laboratory Methods in Freshwater Ecosystems. Nobel Publ., Ankara. (in Turkish).

[13] Demirezen, D., Aksoy, A. (2004): Accumulation of heavy metals in Typha angustifolia (L.) and Potamogeton pectinatus (L.) living in Sultan Marsh (Kayseri, Turkey). Chemosphere 56: 685-696.

[14] DSI (2009): Limnology of Yamula Reservoir. - General Directorate of State Hydraulic Works, Ankara. (in Turkish).

[15] El-Shinnawy, I. A., Abdel-Meguid, M., Nour Eldin, M. N., Bakry, M. F. (2000): Impact of Aswan High Dam on the aquatic weed ecosystem. - ICEHM2000, Cairo University, Egypt.

[16] Fox, A. M. (1992): Macrophytes. - In: Calow, P., Petts, G. E. (eds.) The Rivers Handbook, Vol. 1. Blackwell, London.

[17] Gecheva, G., Yurukova, L., Cheshmedjiev, S. (2013): Patterns of aquatic macrophyte species composition and distribution in Bulgarian rivers. - Turk. J. Botany 37(1): 99-110.

[18] Ibanez, C., Prat, N., Duran, C., Pardos, M., Munné, A., Ginebreda, A., Tirapu, L., Andreu, R., Caiola, N., Cid, N., Hampel, H., Sanchez, R., Trobajo, R. (2008): Changes in dissolved nutrients in the lower Ebro river: causes and consequences. - Limnetica 27(1): 53-64.

[19] Kantrud, H. A. (1990): Sago pond weed (Potamogeton pectinatus L.): A literature review. - U.S. Fish and Wildlife Service Resource Publication, Washington D.C.

[20] Kaplan, Z., Fehrer, J. (2004): Evidence for the hybrid origin of Potamogeton $\times$ cooperi (Potamogetonaceae): Traditional morphology-based taxonomy and molecular techniques in concert. - Folia Geobotanica 39(4): 431-453.

[21] Kaplan, Z. (2008): A taxonomic revision of Stuckenia (Potamogetonaceae) in Asia, with notes on the diversity and variation of the genus on a worldwide scale. - Folia Geobotanica 43: 159-234.

[22] Kazanc1, N., Clergue-Gazeau, M. (1990): Simuliidae de Turquie. I. Premier donnees faunistiques et biogeographiques (Diptera, Simuliidae). - Annales de Limnologie 26: 4550 .

[23] Kazanc1, N., Ertunç, Ö. (2008): On the Simuliidae (Insecta, Diptera) fauna of Turkey. Review of Hydrobiology 1(1): 27-36. 
[24] Kesici, T., Kocabaş, Z. (2007): Biostatistics. - Ankara Univ. Publ., Ankara (in Turkish).

[25] Keskin, E., Unal, E. M., Atar, H. H. (2016): Detection of rare and invasive freshwater fish species using eDNA pyrosequencing: Lake Iznik ichthyofauna revised. Biochemical Systematics and Ecology 67: 29-36.

[26] Kohler, A. (1978): Methoden der Kartierung von Flora und Vegetation von Susswasserbiotopen. - Landschaft \& Stadt 10: 73-85.

[27] Kuhar, U., Germ, M., Gaberscik, A., Urbanic, G. (2011): Development of a river macrophyte index (RMI) for assessing river ecological status. - Limnologica 41: 235243.

[28] Kumar, S., Stecher, G., Li, M., Knyaz, C., Tamura, K. (2018): MEGA X: molecular evolutionary genetics analysis across computing platforms. - Molecular Biology and Evolution 35(6): 1547-1549.

[29] Madson, J. D., Chambers, P. A., James, W. E., Koch, E. W., Westlake, D. F. (2001): The interaction between water movement, sediment dynamics and submersed macrophytes. Hydrobiologia 444: 71-84.

[30] Melzer, A. (1999): Aquatic macrophytes as a tool for lake management. - Hydrobiologia 395/396: 181-190.

[31] Santamaria, L. (2002): Why are most aquatic plants widely distributed? Dispersal, clonal growth and small-scale heterogeneity in a stressful environment. - Acta Oecologia 23: 137-154.

[32] Schneider, S., Melzer, A. (2003): The trophic index of macrophytes (TIM) - a new tool for indicating the trophic state of running waters. - Internat. Rev. Hydrobiol. 88: 49-67.

[33] Seçmen, Ö., Leblebici, E. (1997): Wetland Plants and Vegetation of Turkey. - Ege Univ. Fac. of Sci. Publ., İzmir. (in Turkish).

[34] Štorchová, H., Hrdličková, R., Chrtek, J., Tetera, M., Fitze, D., Fehrer, J. (2000): An improved method of DNA isolation from plants collected in the field and conserved in saturated $\mathrm{NaCl} / \mathrm{CTAB}$ solution. - Taxon 49: 79-84.

[35] Ter Braak, C. J., Smilauer, P. (2002): CANOCO reference manual and CanoDraw for Windows user's guide. - Software for canonical community ordination (version 4.5).

[36] Vestergaard, O., Sand-Jensen, K. (2000): Alkalinity and trophic state regulate aquatic plant distribution in Danish lakes. - Aquatic Botany 67: 85-107.

[37] Wade, P. M. (1994): Management of Macrophytic Vegetation. - In: Calow, P., Petts, G. E. (eds.) The Rivers Handbook. Hydrological and Ecological Principles, Vol. 2. Blackwell, Oxford.

[38] Westlake, D. F. (1986): The direct determination of biomass of aquatic macrophytes and measurement of underwater light. - HMSO, London.

[39] Wetzel, R. G., Likens, G. E. (1991): Limnological Analyses. $2^{\text {nd }}$ ed. - Springer, New York.

[40] Yıldız, K., Özkıran, Ü. (1991): Diatoms of Kız1lırmak river. - Turk. J. Botany 15: 166188. (in Turkish).

[41] Yılmaz, A., İnci, A., Tunçbilek, A. Ş., Yeşilöz, H., Koçak, Ö., Şirin, Ü., İça, A., Yııldırım, A., Demircioğlu, A., Düzlü, Ö. (2007): An outbreak of black fly (Simulium (Wilhelmia) lineatum) (Diptera: Simuliidae) in central basin of Kizllırmak river. - Journal of Erciyes Univ. Vet. Fac. 4(2): 91-95. (in Turkish).

[42] Yılmaz, A., Yeşilöz, H., Demircioğlu, A. (2010): Investigations on control of Simulium spp. (Diptera: Simuliidae) in Cappadocia region of Turkey. - Ekoloji 19(77): 107-112. (in Turkish). 